\title{
Maria: mareo referencial e consolo para Lutero em sofrimento
}

Recebido: 28/06/2017. Aprovado: 11/08/2017.

\section{Ivoni Richter Reimer*}

Resumo: Este artigo apresenta textos sagrados cristãos e islâmicos que narram sobre Maria, destacando seus conteúdos centrais. Concentra no Magnificat de Maria na interpretação de Lutero, na obra "Magnificat: O Louvor de Maria", de 1521. Contextualiza esta obra e analisa seu conteúdo teológico e político-social, bem como eclesiástico. Esboça elementos e aspectos para contribuir em diálogos ecumênicos.

Palavras-chave: Maria. Bíblia e Hermenêutica. Lucas 1,46-55. Magnificat de Lutero. Ecumenismo.

Abstract: This article presents Christian and Muslims sacred texts about Mary, highlighting its central contents. It focusses on Luther's interpretation of the "Magnificat: Mary's praise", dated from 1521. From the historical context, analizes its theological and socialpolitical as well as its ecclesiastic issues and outlines elements and aspects for a contribution to the ecumenic dialog.

Keywords: Mary. Bible and hermeneutics. Luke 1:46-55. Luther's Magnificat. Ecumenism.

* Pós doutora em Ciências Humanas (UFSC). Doutora em Teologia/Filosofia (Kassel Alemanha). Graduada em Teologia (EST). Bolsista Produtividade CNPq. Pastora da Igreja Evangélica de Confissão Luterana no Brasil. Docente nos Programas de Pós Graduação em Ciências da Religião e em História na PUC Goiás.

E-mail: ivonirr@gmail.com 


\section{Introdução}

Perguntada por potenciais contribuições marianas para diálogos ecumênicos, coloquei-me a refletir acerca de algumas questões: $\mathrm{O}$ que se entende por 'marianas'? A partir do que posso contribuir, tendo em vista diálogo e ecumenismo? Em que diálogo e relações ecumênicas pensamos, e em interesse de que e de quem estão?

Inquietada e simultaneamente convidada a mais uma vez encontrar com Maria, esbocei alguns critérios de seleção para abordagem da questão. Para introduzir, tratarei do tema pelo viés de textos sagrados cristãos canônicos, apócrifos e muçulmanos, que serão as fontes. Neste percurso, observarei elementos teológicos e exegéticos, inspirados pela brisa hermenêutica de libertação. Deter-me-ei, então, à interpretação que Lutero fez de Maria, principalmente quando tratou do Magnificat (Lucas 1,46-55), e das potencialidades que podemos ecumenicamente perceber e viver a partir disto.

\section{Maria nos textos sagrados}

Começo com o elenco e alguma apresentação de textos sagrados que fizeram registro de aspectos que foram e/ou se tornaram relevantes acerca de Maria. Neste tópico, o objetivo é registrar e brevemente comentar as passagens de textos sagrados, nos quais Maria é mencionada como personagem, protagonista e crente em Deus. Sua fé é judaica, e sua espiritualidade é de ação e devoção em resposta ao amor primeiro de Deus. Ela serve de exemplo de fé e é reconhecida, pela religião cristã, como mãe de Jesus, o Cristo, prometido pelas profecias, Filho de Deus (Mc 1,1; Mt 1,1.16; Rm 1,1-5). Vejamos em partes:

\subsection{Maria em Paulo apóstolo}

O texto mais antigo que existe sobre Maria encontra-se escrito pelo apóstolo Paulo, em Gl 4,4, no contexto teológico-social e literário em que discursa sobre a ação salvífica de Deus por meio do envio de seu Filho e sobre a nossa filiação a Deus por seu intermédio. O nome de Maria nem sequer aparece: "[...] vindo, porém, a plenitude do tempo, Deus enviou seu Filho, nascido de mulher, nascido sob a lei, para [...]". Na concepção de Paulo, este envio ocorre por meio do nascimento, por meio do corpo de mulher, por meio da gravidez e do parto, de acordo 
com a lei e os costumes vigentes dentro das relações de pertencimento ao povo judaico naquele tempo histórico e religioso. $\mathrm{O}$ apóstolo não entra em detalhes e não questiona 'como' isto aconteceu. A ele interessa argumentar a "nossa filiação" com base nessa encarnação do Filho de Deus, como cumprimento da Torá. Nada mais Paulo menciona acerca de Maria.

\subsection{Maria nos Evangelhos}

O mais antigo evangelho, Marcos, também não detalha pormenores acerca do nascimento de "Jesus Cristo, o Filho de Deus" $(1,1)$. Nele não aparecem as narrativas da anunciação, do nascimento e da infância de Jesus e, portanto, Maria não tem destaque nessas ocasiões. Em Marcos, ela é mencionada apenas duas vezes: em Mc 3,31-35, onde aparecem a mãe e os irmãos e irmãs de Jesus ${ }^{1}$, e em 6,3 , onde o povo se admira da sabedoria de Jesus, perguntando: [...] Não é este o carpinteiro, o filho da Maria, e irmão de Tiago e José e Judas e Simão? E as irmãs dele não vivem aqui junto de nós?"

O evangelho de Mateus menciona Maria na genealogia de Jesus $(1,16)^{2}$, na narrativa do nascimento, da visita dos reis magos, da fuga para o Egito e no seu retorno a Israel $(1,18-25 ; 2,11 ; 2,13-15 ; 2,20-21)$. Também aqui Maria aparece junto aos irmãos de Jesus $(12,46-50 ; 13,55)$.

Lucas é o evangelho que dá maior destaque à anunciação e à gravidez de Maria e ao nascimento de Jesus. Durante a gravidez, ela visita sua prima Isabel (1,36.39-56), e nesse contexto entoa o Magnificat $(1,46-55) .{ }^{3}$ Ela também está presente, com José, no recenseamento e na difícil viagem até Belém, na visita dos pastores, no templo e diante de $\mathrm{Si}$ meão $(1,26-38 ; 1,39-45 ; 1,46.56 ; 2,4-7 ; 2,16.19 ; 2,27.33-34)$. Maria está

1 Veja discussão e bibliografia sobre a questão da tradução e compreensão do termo adelfoi, adelfai e méter em relação a Maria em RICHTER REIMER, Ivoni. Compaixão, cruz e esperança: Teologia de Marcos. São Paulo: Paulinas, 2012; RICHTER REIMER, Ivoni. Maria sempre bendita: textos e imaginários de uma história que se faz, desfaz e refaz. In: (Org.). Imaginários da divindade: textos e interpretações. Goiânia: Ed. da UCG; São Leopoldo: Oikos, 2008. p. 101-124.

2 Acerca da genealogia, ver vários artigos em Revista de Interpretação Bíblica Latino Americana, Petrópolis, v. 46 (2003) e especificamente, no v. 44 (2003), p. 37-59: RICHTER REIMER, Ivoni. E a salvação se fez corpo: Lc 1-2 numa perspectiva feminista.

3 Ver análise deste cântico em SOUZA, Carolina Bezerra de. Magnificat: o canto do corpo grávido e pobre. In: RICHTER REIMER, Ivoni (Org.). Por Amor à Vida: crenças, resistências e conquistas na Bíblia e na Atualidade. Goiânia: Ed. da PUC Goiás, 2015. p. 93-110. 
junto de sua família e participa da peregrinação a Jerusalém, no templo $(2,41.48 .51)$. Ela aparece junto de seus outros filhos $(8,19-21)$, e Maria e seus seios são benditos por uma mulher anônima, após enunciado de Jesus $(11,27)$. Lucas também menciona Maria como discípula de Jesus, após sua ressurreição, em Jerusalém (At 1,14).

O evangelho de João, assim como Marcos, não narra o nascimento de Jesus, e Maria é mencionada também apenas duas vezes: num casamento em Caná da Galileia (2,1-12), onde também são mencionados os irmãos de Jesus; junto à cruz, ao lado de sua irmã anônima (19,25-27).

Resumindo e comentando: Para Marcos, Maria aparece como mãe de Jesus em situações conflitivas. Assim como para ele, João não se ocupa com a questão da virgindade, da gravidez e do nascimento de Jesus. Mateus, porém, tratava da tradição judaica da concepção virginal (Isaías 7,14) de Jesus, sem contudo, dar-lhe muita ênfase: Maria estava prometida em casamento, era noiva de José e, sem terem coabitado, engravidou. Pela lei judaica, a gravidez seria prova de adultério, pelo qual a noiva poderia ser julgada e condenada; por não denunciá-la, José é qualificado como justo. Também Lucas trabalha a tradição da concepção virginal, ampliando-a para o mundo greco-romano: evoca-se uma nova criação que abrange o mundo todo por meio do Espírito (Gn 1,2; Lc 1,34-35). Em Lucas, Maria praticamente é autônoma em relação a José e é protagonista da ação hierofânica, sendo com ela que o anjo se comunica; ela vai sozinha até as montanhas de Judá para visitar Isabel, em cujo encontro nova hierofania acontece no ventre das duas grávidas, que se expressa pela bendição feita por Isabel para Maria. Como resposta, o Magnificat de Maria elabora tradições e experiências pessoais e históricas, do presente e do passado: Maria é teóloga. Em João, as comunidades recordam de Maria como mãe e discípula de Jesus, bem como testemunha de sua ressurreição.

\subsection{Maria nos apócrifos}

Os textos do Novo Testamento foram canonizados no decorrer de longo processo de debates teológicos nos quatro primeiros séculos. ${ }^{4}$

4 Acerca do processo de canonização, ver os artigos diversos na Revista de Interpretação Bíblica Latino Americana, Petrópolis, v. 42-43, 2003 e também MURAD, Afonso. Maria, toda de Deus e tão humana. 3. ed. São Paulo: Paulinas; Valência: Siquém, 2009. p. 87-89. 
Contudo, os conflitos não findaram, e, para além dos conflitos de interpretação, houve também retomados esforços de manter vivas outras tradições relativas à vida e morte de Maria, existentes já no século II. Estas estão parcialmente registradas nos apócrifos Protoevangelho de Tiago e nos Fragmentos Coptas. ${ }^{5}$

No Protoevangelho de Tiago é narrado o nascimento de Jesus $e$ o nascimento de Maria, a infância dela e o seu casamento com José. Entre muitos detalhes, destaco, aqui, a importância que a concepção virginal adquiriu em alguns grupos gnósticos da Antiguidade, sendo que a própria Maria teria nascido por meio de ação miraculosa de Deus: seu pai Joaquim era estéril e sua mãe, Ana, teria concebido virgem. Esta família teria se dedicado ao serviço do templo, onde aos 12 anos Maria foi entregue, pelos sacerdotes, ao velho José, que passou a realizar seus trabalhos de construção em outros lugares. O anjo apareceu, anunciou o nascimento de Jesus e Maria concebeu, tornou-se alvo de muita difamação e gozação, sendo que o sumo sacerdote confirmou, por meio de ritual religioso, a concepção sem que José tivesse coabitado com a "virgem do Senhor". Em comparação com os evangelhos canônicos, nota-se a intensificação da importância da concepção virginal - de mãe pra filha - para argumentar em favor da divindade de Jesus, o que pode ser compreendido no contexto sociocultural, em que se busca fundamentar as incipientes celebrações da conceição de Maria. Detalhe teológico relevante é que, aqui, o anúncio do anjo pressupõe que Jesus é Deus e Maria, a mãe de Deus: "Tu serás mãe do Altíssimo". Estas diferenças e embates em relação aos escritos canônicos contribuíram para a formulação do primeiro dogma mariano, no século IV, ${ }^{6}$ o de Maria Theotokos, Mãe de Deus.

Em gênero literário de evangelho, os Fragmentos Coptas (séc. V-VI) apresentam Maria como personagem importante no relato da ressurreição de Jesus. Ela é testemunha da ressurreição de seu filho Jesus, e conversa com o ressurreto, recebendo dele a incumbência de reunir os discípulos e lhes dizer para irem à Galileia e lá encontrá-lo. O ressurreto não lhe permite tocar nele, mas lhe atesta que o mesmo corpo ressurreto

5 As citações e conteúdos aqui anotados baseiam na obra de SCHNEEMELCHER, WiIhelm (Hg.). Neutestamentliche Apokryphen in deutscher Übersetzung. 5. ed. Tübingen: Mohr, 1987, v. I. Ver maiores detalhes narrativos e históricos em RICHTER REIMER, Ivoni. Maria, Jesus e Paulo com as mulheres: textos, interpretações e história. São Paulo: Paulus; São Leopoldo: CEBI, 2013. p. 21-26.

6 Ver questões históricas e teológicas sobre os dogmas marianos em Afonso Murad (2009). 
é o corpo que passou "nove meses em teu seio". ${ }^{7}$ Outro diálogo de Maria acontece com o jardineiro Filogênio, pelo qual ela é reconhecida como "Maria, a mãe do Filho de Deus", caracterizada, então, mais uma vez pelo ressurreto por meio de sua bênção como "a virgem". O contexto histórico-teológico deste apócrifo indica para acirradas disputas teológicas entre divindade e humanidade de Jesus, provavelmente após o Concílio de Éfeso (431) e antes do Concílio de Constantinopla (553), que declarou o dogma da virgindade eterna.

Resumindo: Nos textos apócrifos, Maria tem importância como mãe de Jesus, como praticante da fé judaica, como discípula e testemunha da ressurreição de Jesus, tendo sido por ele enviada para anunciar a Boa Nova aos demais discípulos e discípulas. Neste sentido, ela figura como apóstola incumbida do anúncio da ressurreição, assim como Maria Madalena. Contudo, esta importância vem acompanhada de uma marca maior: ela é mais do que qualquer outra mulher que se relacionava com Jesus. Ela é sua mãe, e tem especial lugar junto a ele. Neste contexto, é preciso observar, também para outras pesquisas e abordagens, que, sempre quando se debate e se decide sobre a divindade e humanidade de Jesus, Maria aflora na discussão teológico-eclesiástica por meio da importância de sua virgindade para sustentar a divindade de Jesus, e assim também indicar para a especial proximidade de Maria com Deus. ${ }^{8}$ Esta percepção antropológica de Maria é semelhante no Islamismo, apesar da diferença profundamente teológica.

\subsection{Maria no (Al)corão}

O livro sagrado do Islamismo é composto por 114 surahs (capítulos), compostos no século VII por Maomé. Maria é mencionada em dois capítulos, junto com Jesus e João Batista. Em 3,33-37 é relatado o nascimento de Maria, cujo pai 'Imran (Joaquim) era sacerdote em Nazaré e cuja mãe (anônima) era estéril; por intervenção de Alá, ela deu à luz a Maria, que foi dedicada ao serviço ao templo. O surah 19 é dedicado todo ele a Maria,

7 O texto traduzido e transcrito encontra-se em Ivoni Richter Reimer (2013, p. 24-25).

8 Há ainda a narrativa apócrifa, Trânsito de Maria, do Pseudo-Militão de Sardes (séc. VI-VII), que narra a morte e a condução da alma, a ressurreição de Maria por Jesus ressurreto ao céu. Afonso Murad (2009, p. 128) apresenta alguns detalhes dessa narrativa, esboçando o panorama histórico da Assunção de Maria, que tornou-se dogma por meio da bula papal Munificentissimus Deus, em 1950. Este dogma mariano é especificamente católico romano, enquanto que os anteriores à Reforma são ecumênicos. 
anunciação do anjo e nascimento de Jesus, alternando várias passagens do Antigo Testamento com narrativas cristãs apócrifas existentes. Maria é apresentada como virgem, tendo sido engravidada pelo "sopro de Alá". Jesus nasceu perto de Belém, quando Maria se encontrava sob um pé de tamareira e sofria as dores do parto. Maria clama e Alá socorre, dizendo para sacudir a tamareira e comer de seus frutos, fazendo brotar uma fonte de água fresca a seus pés. Jesus nasce e Maria o apresenta à sua família. $\mathrm{O}$ Alcorão apresenta Jesus como "filho de Maria, a Palavra de Alá" (19,35), mas não como Filho de Alá-Deus. Isto significa que Maria não é reconhecida como mãe de Deus. Até hoje, no Islamismo, são dedicadas orações e veneração a Maria, como virgem mãe de Jesus.

Resumindo: O Islamismo reconhece a importância de Maria como mãe de Jesus, sendo que Maria e Maomé, bem como Maomé e Jesus são igualmente portadores da palavra de Deus 9 . No uso que o surah 19 faz de narrativas apócrifas cristãs, percebe-se o traço comparativo entre Agar e Maria: ambas deram à luz no deserto, sozinhas, e foram favorecidas pela intervenção divina; trata-se de mães de duas 'novas nações'-religiões. Talvez por isso, o respeito e a devoção popular muçulmanas são elementos importantes em relação a Maria, também como modelo de dedicação a Deus/Alá.

No século VII, quando o Alcorão foi escrito, os dogmas de Maria Mãe de Deus e Maria Virgem Eterna já estavam promulgados, e o Islamismo apenas reconhece que Maria é mãe de Jesus, profeta-portador da palavra de Deus, assim como Maomé. No Cristianismo, porém, as decisões conciliares em torno da divindade e humanidade de Jesus também sempre afetavam Maria e o lugar que ela deveria ocupar junto à Trindade ${ }^{10}$, implicando isso também a espiritualidade e as práticas devocionais. Adentramo-nos, assim, no tempo em que vivia Lutero e na importância com a qual Maria se lhe revelou.

\section{Maria em Lutero}

Como Lutero entendia Maria e com ela se relacionava? Em que ela se mostrou relevante no trabalho hermenêutico-teológico daquele

9 O significado de Maria foi analisado por PELIKAN, Jaroslav. Maria através dos séculos: seu papel na história da cultura. Tradução de Vera C.Guarnieri. São Paulo: Companhia das Letras, 2000. p. 97-114.

10 Sem poder adentrar nessa discussão, ver Pelikan (2000) e BOFF, Clodovis. Mariologia Social: o significado da Virgem para a sociedade. São Paulo: Paulus, 2006. 
monge agostiniano, naquele conturbado tempo, na primeira metade do século XVI? Duas fontes são centrais para entendermos como Lutero compreendia Maria: o seu livro Magnificat: o louvor de Maria, de $1521^{11}$, e a explicação do Segundo Artigo do Credo Apostólico, contida no Catecismo Maior, de 1529. Ali, refere-se a Maria apenas como mãe do Senhor, Virgem. Já no livro, podemos encontrar maiores detalhes de como Lutero se referia a Maria e como ela lhe era importante.

\subsection{Apresentação da obra e da importância de Maria}

Em termos de contextualização, Lutero escreveu o seu Magnificat em meio a reações e apoios aos debates teológicos, tornados públicos a partir da publicação e divulgação das 95 teses que refletiam a experiência e a descoberta da justificação por graça e fé e, por isso, contestavam a prática das indulgências e os abusos do poder eclesiástico. ${ }^{12} \mathrm{~A}$ partir de 1517, Lutero sofreu uma dinâmica de adesões e represálias, ameaças e processos disciplinares que culminaram na bula Exsurge Domine, de 15 de junho de 1520, que acusava Lutero de heresia. Esta foi queimada por Lutero, na Universidade de Wittenberg, durante protestos contra a Cúria, que imediatamente reagiu com a bula Decet Romanum Pontificem, que declarava a excomunhão de Lutero (03 de janeiro de 1521). É nesse contexto que Lutero recebeu e respondeu a carta do príncipe João Frederico, sabendo que poderia contar com seu apoio. Na sequência, Lutero não atendeu à ordem de retratação exigida por Roma, sendo então convocado pelo imperador Carlos V para se apresentar na Dieta de Worms, em abril de 1521, na qual também não abriu mão de suas convicções. Saiu de Worms com a ameaça imperial da proscrição. No caminho de volta, foi então 'sequestrado' por ordem do príncipe eleitor Frederico, o Sábio, e foi levado para Wartburgo, onde permaneceu asilado como 'cavalheiro Jorge'. A proscrição foi concretizada com o Edito de Worms, assinado pelo imperador em 26 de maio de 1521. Excomungado, Lutero também foi destituído de seus direitos políticos por causa da acusação de erros doutrinais, como a doutrina dos sacramentos, do servo-arbítrio, rebelião contra autoridades da igreja e do Estado, desrespeito aos concílios. Uma

11 LUTERO, Martim. Magnificat: o Louvor de Maria. Adaptação do texto: Rui J.Bender. 2. impr. São Leopoldo: Sinodal; Aparecida: Santuário, 2015 [1521]. [Versão atualizada de Obras Selecionadas de Martinho Lutero. V. 6. São Leopoldo: Sinodal; Porto Alegre: Concórdia, 1996].

12 Este breve resumo baseia-se em DREHER, Martin N. História do Povo de Deus: uma leitura latino-americana. São Leopoldo: Sinodal, 2013. p. 230-254. 
ordem de prisão também foi expedida para seus adeptos, e a divulgação de suas obras foi proibida... "Com suas determinações, o Edito de Worms apresenta-nos um dos traços mais característicos da Contrarreforma, que é o controle eclesiástico sobre a vida intelectual e religiosa." (DREHER, 2013, p. 238). Nessas condições, asilado em Wartburgo até março de 1522, Lutero traduziu o Novo Testamento e escreveu várias obras, entre elas o Magnificat, em que analisa o Magnificat de Maria (Lucas 1,46b-55). Foi com este trabalho que ele encontrou consolo e esperança nas palavras da "doce mãe de Deus". Este acalento está perpassado de avaliação e crítica pessoal, social, eclesiástica e política.

A Apresentação do livro, escrita em Wittenberg, em 10 de março de 1521, dedica o estudo da obra ao príncipe e senhor João Frederico, duque da Saxônia, landgrave da Turíngia e margrave de Meissen, que havia solicitado a Lutero ajuda e orientação para seu governo ${ }^{13}$. Já na Apresentação, Lutero indicou o rumo de sua interpretação do Magnificat de Maria, que é a necessidade de governantes se deixarem governar pela graça e ajuda de Deus, para o bem do povo. Dito de outra forma: a qualidade de vida do povo evidenciará se o governante é governado ou não pela graça de Deus:

Desejo a Vossa Alteza a graça e a ajuda divina. Isso é muito necessário. O bem-estar de muita gente depende de um príncipe tão importante, quando ele é governado pela graça de Deus. Por outro lado, dele depende a desgraça de muitos, quando ele se volta para si próprio e não é governado pela graça (LUTERO, 2015/1521, p. 9).

Por seu conteúdo e abordagem contextualizados, Martin N. Dreher $(2015$, p . 7) nomeia este escrito de "escrito de ética política luterana". Nele foram elaboradas algumas características de Maria: modelo de vida cristã, expressão de vida a partir do Espírito Santo, exemplo da gratuidade do agir de Deus, exemplo de fé e de esperança em Deus, exemplo do agir de Deus na história, tendo por base a vivência da justificação por graça e fé. Emblematicamente, o Magnificat de Maria, na interpretação de Lutero, "é exercício de piedade, de mariologia evangélica, de orientação sobre interpretação da história, e convite para o exercício político

13 DREHER, Martin N. Apresentação. In: LUTERO. Magnificat: o Louvor de Maria. Adaptação do texto: Rui J. Bender. 2. impr. São Leopoldo: Sinodal; Aparecida: Santuário, 2015. [Versão atualizada de Obras Selecionadas de Martinho Lutero. V. 6. São Leopoldo: Sinodal; Porto Alegre: Concórdia, 1996], p. 7, destaca que o príncipe "pedira de Lutero orientação sobre como governar cristãmente". 
responsável" (DREHER, 2015[=1996], p. 8). É nesta trilha que Wanda Deifelt ${ }^{14}$ afirma: "Lutero propõe que Maria sirva de exemplo para uma atitude ética cristã, um modelo especial para governantes." No todo, Maria é tida como modelo de desprendimento e de amor cristão, que não busca seu próprio benefício, como continua a autora: "Ela é serva, como todos os cristãos deveriam ser. [...] Ela remete tudo à graça e à bondade de Deus. Por isto ela se constitui em um exemplo consolador da graça divina. Ela é bem-aventurada porque ajuda a fortificar a fé e a confiança em Deus".

Destacando as ações libertárias de Deus na história do povo e das pessoas, especificamente na vida de Maria, Clodovis Boff (2006, p. 369), contribuindo com diálogos ecumênicos, define "o Magnificat [como sendo] um canto de reconhecimento e não de ressentimento".

\subsection{Maria como referencial hermenêutico luterano}

No desenvolvimento de seus princípios éticos no processo de releitura do Evangelho e de Paulo, também em seu livro Magnificat Lutero reconheceu que o coração humano é sedento por poder e que, por isso, o governante corre o risco de esquecer Deus e desprezar os súditos. É no exercício do poder que se revela a pessoa que o exerce, e, frente a isso, Lutero recomenda: "Todos os que quiserem governar bem e ser boas autoridades devem aprender bem e guardar na memória aquele cântico" (p. 10) ${ }^{15}$, visto que ele conhecia o poder da desastrosa impunidade para as autoridades, e denunciou, aqui, que a prática do mal sem receber castigo transforma a autoridade em monstro, diante do qual o povo não se manifesta, porque tem medo.

Exercitando um de seus princípios hermenêuticos, ou seja, a Escritura interpreta a si mesma, Lutero remete a Romanos 12,8 para imprimir o fluxo argumentativo de sua interpretação do Magnificat: "Quem governa seja solícito", isto é, governe com cuidado, esmero e competência. Para tal, ele toma o "cântico sagrado da bendita mãe de Deus" como o melhor exemplo nas Escrituras, e pede que "a doce mãe de Deus" conquiste para

14 DEIFELT, Wanda. Maria: uma santa protestante? Revista de Interpretação Bíblica Latino-Americana, Petrópolis, n. 46, v. 3, p. 119-134, 2003. Aqui especificamente p. 124-125.

15 A partir de agora, quando me referir ou citar texto do livro de Lutero (2015/1521), a fonte principal, tomo a liberdade de mencionar apenas o número da página, a fim de não tornar o texto cansativo com muitas repetições de nota bibliográfica. 
ele "o espírito capaz de interpretar de forma proveitosa e profunda este cântico" (p. 10), a fim de que o governante e todas as pessoas possam dele ter todo proveito na vida, em ação e louvor.

A Introdução da obra (p. 13-16) elabora a chave hermenêutica e bíblico-teológica com a qual Lutero abriu a compreensão do Magnificat para o príncipe João Frederico, com base no que Deus fez para com Maria: "Deus é um Senhor que não faz outra coisa do que engrandecer o que é humilde, de rebaixar o que é grande, de quebrar o que está feito e de refazer o que está quebrado" (p. 13). Se o príncipe quer governar cristãmente, deverá orientar-se por esta ação básica de Deus! Lutero busca o argumento para esta chave de leitura e interpretação na própria Escritura $^{16}$, a começar pela criação de tudo a partir do nada, passando por uma série de textos do Antigo e do Novo Testamentos. A maior obra de salvação realizada por Deus aconteceu em e por meio de Cristo, que enfrentou o mais profundo abismo, a cruz, para onde Deus olhou em profundidade, ressuscitando-o ao terceiro dia. Este olhar misericordioso e transformador de Deus dirige-se sempre para baixo, em movimento contrário ao olhar humano, que sempre busca as alturas, honra, poder, riqueza, conhecimentos... Assim,

quando constatamos que ele é um Deus que olha para baixo e ajuda somente os pobres, desprezados, miseráveis, desgraçados, abandonados e aqueles que não são nada, ele se torna muito querido. O coração está possuido de alegria, pula e salta por causa da grande estima que recebeu em Deus. Nesse momento está presente o Espírito Santo (p. 14).

Isto foi também o que aconteceu com a "virgem Maria" que, em seu cântico, "fala de experiência própria. Ela foi iluminada e instruída pelo Espírito Santo" (p. 13), e somente assim pôde compreender a vontade de Deus em sua vida. Portanto, o Espírito Santo não apenas possibilita a compreensão da atuação libertadora de Deus no estudo do texto bíblico, mas abre a compreensão para essa ação de Deus na vida! Essa atuação de Deus a partir do reverso da história também é entendida por Lutero com base na menção da profecia de Isaías 11,1-2: para ele, o "tronco de Jessé", no tempo de Maria, já não era mais cheio de honra, glória, riqueza e poder, mas estava representado em Maria, "humilde e pobre mocinha

16 Interessantemente, nessa Introdução, Lutero não faz referência a 1Coríntios 1,26-29, mas a Romanos 12,16, por exemplo. Ele faz esta referência recém no comentário específico de Lucas 1,48 (p. 30). 
[...] que a filha do senhor Anás ou Caifás não teriam considerado digna de ser sua mais humilde criada" (p. 16). Aqui, especificamente Lutero retoma sua chave hermenêutica:

É uma caracteristica de Deus olhar para as coisas insignificantes. Por isso traduzi a palavra humildade por "nulidade" ou "ser insignificante". Portanto, Maria quer dizer o seguinte: Deus olhou para mim, uma moça pobre, desprezada e insignificante. (p. 30)

Esta chave hermenêutica remete para realidades de cunho social, para estruturas de poder e dominação, que não têm sua origem em características biológicas ou naturais, mas nas relações que são construídas. Também aqui, Lutero expressa sua assertiva de forma perspicaz, simultaneamente se distanciando de interpretações que circulam em seu contexto:

Fazem [in]justiça a Maria aqueles que afirmam que ela não se teria vangloriado de sua virgindade, mas de sua humildade. [Contudo], ela não se envaidece de sua virgindade nem de sua humildade, mas unicamente da graciosa observação divina. Por isso a ênfase não está na palavrinha "humildade", mas em "contemplar". Não é sua humildade que deve ser louvada, mas a atenção por parte de Deus. Como quando um príncipe estende a mão a um mendigo: não se elogia a nulidade do mendigo, mas a misericórdia e a bondade do príncipe (p. 30-31). ${ }^{17}$

A crítica de Lutero remete ao centro da afirmação do texto e sua interpretação, que não é nem a virgindade, nem a humildade de Maria, mas a ação transformadora de Deus, afirmada por Maria: "Pois ele baixou os olhos para a humildade-insignificância da sua serva". ${ }^{18}$ No Magnificat de Maria não aparece o termo "virgindade", mas ele foi introduzido na interpretação de Lutero, para rebater as discussões dogmático-teológicas de seu contexto, baseadas em Lucas 1,26ss. Relevante é apenas o fato que Deus "olhou para baixo" e viu a realidade de humilhação na qual vivia Maria; esta é a ação que engendra a obra de misericórdia e salvação.

17 No Magnificat de Lutero, esta é a única menção à virgindade de Maria, temática sem relevância neste escrito. Em outros escritos, porém, Lutero enfatiza esta virgindade (DEIFELT, 2003, p. 125-27). Perceba-se, porém, que se trata de textos bem mais recentes, principalmente o Comentário de Gênesis, que é publicado em 1543 em forma de coletânea de preleções realizadas desde 1535.

18 O verbo epiblépo indica olhar em direção para baixo, comumente traduzido por "contemplar", "atentar". O termo tapéinosis remete para situação de humilhação, pobreza e desprezo, o que Lutero traduziu por "insignificância", e comumente é traduzido por "humildade". Para análise, ver também Souza (2015). 
Lutero fez acurada investigação textual e intertextual para compreender o significado do termo tapéinosis "humildade-insignificância"19 $\mathrm{e}$, com isso, contribuiu de forma relevante na compreensão do termo em sua dimensão social, econômica e cultural. Na época não havia dicionários bíblico-teológicos, com análise lexiológica, semântica e histórica de 'verbetes', como, no caso, psiché "alma" e pneuma "espírito". Por isso, a interpretação por meio da busca do mesmo termo em outros textos bíblicos certamente era demorada e trabalhosa, contando também com o precioso recurso da memorização. Aqui, Lutero o fez - na solidão de Wartburgo! -, buscando entender a origem da alegria e do engrandecimento de Deus, realizados por Maria. Surpreende-me a complexa profundidade dessa análise que é lúcida e simultaneamente apaixonada, utilizando-se também do recurso retórico da primeira pessoa, no caso, Maria, que se mistura com a palavra do intérprete, Lutero, que também interpreta a sua própria existência e encontra consolo no Magnificat de Maria:

Por isso Maria não diz: "Eu enalteço a Deus", mas "minha alma", como se quisesse dizer: Minha vida com todos os meus dons se movimenta no amor de Deus, em louvor e grande alegria. [...] Isso acontece a todos os que são invadidos pela doçura de Deus e por seu Espirito, assim que sentem mais do que conseguem expressar. Pois louvar Deus não é obra humana. Antes é um sofrer alegre e obra exclusiva de Deus, que não se pode ensinar com palavras, mas conhecer somente através de experiência própria (p. 17, meu destaque).

Como Maria, você, ou seja, o indivíduo é sujeito da fé, da confiança, da expressão de dúvida, da disposição ao serviço de Deus! Assim como Maria, a minha alma e o meu espírito, isto é, "todo meu ser, meus sentidos e minhas forças" e minha capacidade intelectiva reconhecem e enaltecem as obras de Deus para comigo. Como Maria, cabe demonstrar isto: "toda a vida e a alma devem emocionar-se, como se tudo quisesse cantar com alegria e dizer o que vive em nós" (p. 22).

Questionando formas de espiritualidade que são capazes de expressar alegria somente quando tudo está bem, Lutero indica para Maria, que, mesmo tendo sido agraciada, "continua tão simples e serena, que

19 É preciso dar-se conta sempre de novo que tal trabalho ocorria de forma absolutamente 'manual' e 'de memória', sem recursos tecnológicos, informáticos ou digitais, como os que temos atualmente. A grande maioria dos manuscritos ainda era cópia redigida manualmente, visto que a imprensa funcionava há pouco tempo. Vale mencionar que C. Boff (2006, p. 339) conclui que o termo tapeínosis exprime a condição de "insignificância social" de Maria, o que Lutero havia defendido em 1521! 
não teria considerado nenhuma empregada inferior a si” (p. 23). Questionando as teologias meritórias, ele afirma em duas direções, ou seja, contra as obras por si mesmas e a favor das obras como expressão de gratidão à salvação pela exclusiva graça de Deus; portanto, a sua crítica à teologia meritória não pode servir de fundamento ou justificativa para indiferença, ingratidão ou inércia:

[...] engrandecem tanto as obras, que acreditam ganhar o céu com elas. Antes de tudo, deveriam anunciar e conhecer a pura bondade de Deus. Pois deveríamos saber que Deus nos salva por pura bondade, sem qualquer merecimento por meio de obras. Também deveríamos fazer as obras sem buscar qualquer recompensa ou vantagem, por amor à pura bondade de Deus, e nada desejar senão sua benevolência. Não deveríamos estar preocupados com a recompensa. Certamente essa virá por si e continuará sem nosso esforço (p. 28).

A exegese literal, exercitada por Lutero na comunhão com homens e mulheres que se insurgiam contra formas de viver e crer naquele contexto, estava mergulhada na espiritualidade que, para sobreviver às dores do mundo, precisava confiar extrema e dolorosamente na misericórdia e na justiça de Deus a partir do reverso, a partir das pessoas humilhadas e insignificantes, que sofriam os revezes das relações de poder e de riqueza e se alegravam exultantemente com sinais de graça e bondade. A análise das palavras adentra o passado escrito e testemunhado e apresenta o presente para o qual quer se tornar significativa. Com isto, contribui para estruturar outro jeito de crer e de viver: "Com a humildade esquecemo-nos de ficar observando a nós mesmos" (p. 33); "Deus não olha para as obras, mas para o coração e a fé, através da qual também age em nós" (p. 35); "você deve sentir-se encorajado a esperar tudo desse Deus que observa com tamanha misericórdia pessoas sem importância, desprezadas, nulas e não as despreza. Assim seu coração será fortalecido em Deus na fé, na esperança e no amor" (p. 39). Com a exegese literal-espiritual, Lutero pôde contribuir para mudança de mentalidade como estruturante de relações de vida:

[...] ofendemos o nome de Deus quando nos vangloriamos e aceitamos honra ou quando nos agradamos conosco mesmos e nos vangloriamos de nossas obras ou bens [..., mas] o nome de Deus é honrado devidamente quando é santificado por nós e não nos atribuímos nenhuma obra, nenhuma glória, nenhuma auto-complacência nisso. Então ele nos toca e nos santifica. (p. 46-7) 
No exercício de compreender a Escritura por meio de sua autointerpretação, Lutero reconhece que isso não acontece automaticamente, mas que necessita da ação do Espírito Santo e da experiência humana. No Magnificat, Lutero desenvolve a categoria da experiência como fundamental no processo interpretativo. Trata-se da experiência de opressão e libertação, da transformação profunda, da experiência da ação divina em nosso corpo, na história. Assim aconteceu com Maria, que, no cântico, "fala de experiência própria" (p. 13) e "com o exemplo da sua experiência e em palavras" (p. 15) nos ensina como conhecer e louvar Deus.

Esse exercício de tradução, interpretação do texto, do passado e do presente, permite que Lutero perceba a história como dinâmica, e a Palavra de Deus como viva e inclusiva de realidades atuais, visto que só conhecemos Deus por meio de suas obras, reveladas, "e que sentimos e experimentamos” (p. 14). Nesse exercício de compreensão, é possível olhar para a atualidade, para personagens e situações a partir de como Deus tem se revelado e articular avaliações, orientações, comparações, emitir juízo e propor ações.

A exegese de Lutero é contextual no sentido de contemplar o cotidiano e as realidades de poder e riqueza e de opressão e miséria, lendo-os e avaliando-os a partir da Escritura. Várias vezes ele se refere a Maria, de origem humilde, cujo pai e mãe eram "pobres, desprezados e humildes", moça jovem pobre e humilde, diferente das mulheres ricas e instruídas do seu tempo e de "hoje":

as filhas dos sumos sacerdotes e conselheiros de Jerusalém eram mais ricas, belas, jovens e cultas; tinham uma boa reputação em todo o país, assim como as filhas dos reis, príncipes e ricos de hoje. [...] Maria não era filha de gente importante em Nazaré, sua cidade natal, mas de um cidadão simples e pobre. Não tinha nenhuma importância nem estima especial. Foi uma moça comum no meio dos vizinhos e suas filhas, que cuidava dos animais e dos trabalhos domésticos. Não era nada diferente de uma pobre doméstica de hoje, que faz o que é mandada (p. 15).

O cotidiano e as diferentes experiências de classe, gênero e status perpassam o Magnificat de Lutero, destacando sempre a espiritualidade e a experiência como centrais na vivência da fé. Isto é relevante para nosso estudo de Lutero e sua hermenêutica. 


\subsection{Maria entre o texto e o contexto de Lutero}

Utilizando-se da análise terminológica a partir de Lucas 1,46, que destaca a alma como lugar de onde se origina o louvor de Maria, Lutero tece paralelos críticos em relação a grupos religiosos de seu tempo, como eremitas, franciscanos pé-descalços e mestres de falsa piedade, que se esforçam por "alcançar a bem-aventurança com jejuns" (p. 19) e várias práticas de orações e obras "inventadas exclusivamente por seres humanos" para mortificar o corpo. Ele questiona essas práticas, porque percebe que as pessoas começam a confiar cada vez mais nas obras, dando menos atenção à fé, por meio da qual Deus santifica a pessoa em totalidade, "de forma que o espírito, a alma e o corpo sejam santos" (p. 19). Com a análise do Magnificat de Maria, afirma-se, por meio da fé, o processo de santificação do corpo todo!

Com o mesmo recurso analítico em relação à origem do louvor de Maria, que brota da experiência da salvação de Deus e se faz com todo seu corpo, Lutero também dirige sua crítica aos que fazem shows de louvor e adoração com o Magnificat de Maria apenas quando estão bem e saciados de bens:

Hoje, todo o mundo está cheio desse tipo de servir e louvar Deus com canto, pregação, música de órgão, flautins. O Magnificat é cantado maravilhosamente. Ao mesmo tempo, é lamentável que usemos esse precioso cântico de modo completamente destituído de força e graça. Cantamos apenas quando estamos bem; mas quando as coisas vão mal, termina o canto. Nada mais se quer saber de Deus (p. 22).

Lutero não se opunha a cantar o Magnificat, que fazia parte da Oração das Horas, na parte vespertina. Contudo, a partir de suas observações, experiências e estudos, ele questionava o modo como isso era feito, espiritualmente "destituído de força e graça". Remetendo para João 4,24, sua crítica aponta para a incongruência entre fé e ritualística:

Em todas as igrejas ouve-se hoje muito badalar de sinos, música, canto, gritaria e leitura. Mas receio que muito pouco louvor a Deus [...] Então nos comportamos como se Deus fosse surdo e de nada soubesse, como se o quiséssemos acordar e instruir. Esse falso conceito a respeito de Deus colabora mais para sua desonra do que para sua honra (p. 42).

Assim, para Lutero, cantar um verdadeiro Magnificat seria permitir que Deus atue em nós, como Maria o fez, sem disso tirar vantagem 
para si, mas ter essa atuação e testemunhá-la como "consolo, alegria e confiança em Deus" (p. 23).

A partir do reconhecimento da salvação misericordiosa de Deus, a crítica de Lutero torna-se dura em relação a duas práticas sócio-religiosas existentes em seu tempo: a prática das boas obras de forma meritória, numa lógica de coação divina, do toma-lá-dá-cá, e a prática das ordens mendicantes. Ambas são questionadas por apontarem mais para si do que para Deus, correndo o risco de serem alvo de idolatria. Em relação à primeira, que Lutero avaliou como "detestável abuso" (p. 35), ele constatou que

o mundo de hoje está cheio de falsos pregadores e santos [...] que pregam como realizar boas obras [...] não por amor à pura bondade de Deus, mas por interesse próprio. Se não existissem céu e inferno e se a bondade de Deus não lhes prometesse nenhuma satisfação, esqueceriam sua bondade sem amar nem honrá-la. Todos são aproveitadores e mercenários. [...] Transformam a si próprios em ídolos [...] Seu salvador são seus bens, com os quais Deus tem que servir-lhes como um criado (p. 27-28).

Trata-se da crítica de uma mentalidade medieval (que parece reacender em tempos atuais) de que, para receber bens, emprego, bom casamento e poder, é necessário agradar a Deus com alguma oferta, seja por meio de obra beneficente, de doação para a igreja, de realização de rezas e procissões, de compra de indulgência, entre outras. Para conquistar a salvação, ou o céu, as pessoas se passavam por bondosas, colocando-se elas próprias como dignas de honra, gratidão e reconhecimento, ocupando, assim, o lugar de Deus. Os bens serviam como meio de barganha, tanto para conquistar respeito e honra entre as pessoas, quanto para conquistar a graça de Deus... Lutero não poupava críticas a esta prática.

Em relação à segunda prática e com base na análise de Lucas 1,48 , na humildade de Maria, Lutero questiona as ordens mendicantes que se apresentam de maneira humilde, em roupas e posturas, mas que pretendem reconhecimento na terra e no céu. Isso nada mais seria do que falsa humildade, ou "humildade fantasiada", que "nunca se dá conta de que ela é arrogante", porque intenciona alcançar coisas grandiosas em troca. Arrogantes, "desprezam a si próprios e, ao mesmo tempo, não querem ser rejeitados por ninguém” (p. 31-32). A falsa humildade busca "secretamente as coisas elevadas ou a auto-complacência, o que significa a ruína completa da humildade" (p. 34). Ele critica, também de forma 
irônica e destacando a premissa da fé, a intenção de adquirir maior grau de santidade por meio de aparência e afastamento do mundo: "[...] levar as pessoas ao céu por meio de comida, moradia e enterro de convento. Que Deus me ajude! Uma vestimenta de monge pode justificar e salvar - isto é estupidez! Para que ainda se precisa da fé? Vamos virar todos monges ou morrer em hábitos de monge!” (p. 35).

A exegese contextual de Lutero, exercitada na interpretação do Magnificat de Maria, junto com a experiência e o cotidiano, toma como referência e também critica práticas religiosas que chamam mais a atenção a si mesmas do que enaltecem a Deus, como o fez Maria. Maria, com todo seu ser, engrandeceu a Deus, porque ele lhe fez coisas boas. Ela não engrandeceu a si mesma e nem buscou sua própria honra pelo fato de Deus ter feito grandes coisas para ela! A partir deste detalhe, Lutero denuncia a soberba dos ricos e poderosos: "querem ser honrados e admirados [...] Apreciam seus grandes bens que são obra de Deus neles, agarram-se a eles e os consideram como sua propriedade. Julgam-se especiais [... e são] orgulhosos e complacentes consigo mesmos" (p. 22). Ao contrário deles, Maria não reteve para si as grandes coisas que Deus lhe fez, mas devolveu tudo a Deus, para sua honra e glória, e não desprezou ninguém por causa de ter sido a escolhida. Diferente dos ricos e poderosos, das hierarquias eclesiásticas e dos suntuosos shows litúrgicos, ela engrandece e louva Deus, dispondo-se a ser "um alegre albergue e uma serviçal anfitriã desse hóspede" (p. 23).

Compreender e cantar o Magnificat significa, para Lutero, desistir do orgulho e da prepotência, colocar-se a serviço de Deus no serviço ao próximo que precisa do amor de Deus, voltando nosso olhar para baixo, assim como Deus faz, colocar-se junto com pessoas empobrecidas. Esta prática de conversão e solidariedade, contudo, é muito difícil: "Quando temos alguns bens, poder ou honra, quando somos um pouco mais bonitos do que outros, não somos capazes de nos colocar em pé de igualdade com uma pessoa mais humilde" (p. 23). Assim, tomar Deus, louvado por Maria, como referencial para a vida, é aprender a olhar para baixo e buscar reverter situações de desigualdade.

Com base em Lucas 1,52, Lutero reflete sobre o fato de que, na história, sempre houve e haverá autoridade, governo, poder e tronos, e que muitos já foram os governos destituídos por Deus, quando esses "por muito tempo" abusaram de seu poder, praticando injustiça e violência, não temendo a Deus nem respeitando as pessoas. Ele utiliza a palavra de 
Maria para afirmar que Deus não destrói os tronos, mas "a arrogância e os arrogantes", que usam do poder em "proveito próprio" (p. 64). Se Deus derruba poderosos, em consequência, "exaltar os humildes" significa muito mais do que colocá-los no trono; Deus lhes concede o poder de, a partir de baixo, julgar as formas de governo e os governantes! Não se trata simplesmente de uma troca de pessoas no exercício do poder, mas de um empoderamento das pessoas humildes, simples e pobres que as torna capazes de discernir as tramas nas/das relações de poder! De forma ilustrativo-pedagógica, Lutero utiliza ditos populares do seu tempo "Quanto mais instruído, mais pervertido"; "Príncipe é ave rara no céu" -, para demonstrar quão difícil é governar cristãmente. E então conclui que as palavras de Maria acerca do derrubar e elevar foram ditas "para consolo dos sofredores e pavor dos tiranos, se por acaso tivéssemos fé suficiente para acreditar nisso" (p. 65). A dúvida da fé, a angústia e paradoxalmente a liberdade profunda que a verdade causa são realidades que acompanharam Lutero na interpretação do Magnificat de Maria, e mostram que não foi nada fácil realizar a tarefa de, como capelão do príncipe, orientá-lo a governar de acordo com a vontade de Deus.

Lutero fez muitos questionamentos, buscando orientar a atenção para o que realmente importa, ou seja, a fé e a humildade que sabem que tudo provém da gratuita bondade e misericórdia de Deus e a ele se deve devolver tudo, como expressão de honra e glória somente a ele, tomando Maria como exemplo:

É preciso ficar atento, porque nesta vida não podemos abrir mão dos bens de Deus. Portanto, também não podemos viver sem nome e honra. Quando alguém nos elogia e nos conquista boa reputação, devemos tomar por exemplo a mãe de Deus. [...] Porém ninguém deve aceitar a honra como dada a ele e nem guardá-la para si. Devemos santificá-la e devolvê-la a Deus, ao qual pertence, juntamente com todos os bens e obras que são o motivo da honra (p. 47).

Dar honra e glória e servir a Deus, com base em Maria, levou Lutero a questionar o "serviço de Deus" existente em seu tempo, tornando-se também este um alvo de crítica a partir do final do Magnificat de Maria, que retoma a misericórdia de Deus como central na sua principal obra, a "humanização do Filho de Deus" (p. 73) ${ }^{20}$, ou seja, Deus torna-se gente

20 A tradução não me parece ter sido muito feliz. No alemão original de Lutero consta die vormenschung gottis, que SEILS, Martin. Das Magnificat verdeutscht und ausgelegt, 1521. In: DELIUS, Hans-Ulrich (Hg.). Martin Luther: Studienausgabe. Bd. 1. 3.Nachdr. 
em Jesus, filho de Maria: serve-se a Deus, deixando que Deus seja Deus e realize sua obra em nós. Assim fez Maria, a "serva do Senhor"; assim fez Israel, "servo de Deus". Concluo este tópico com as palavras de Lutero, que podem servir de convite ou desafio para reflexão de práticas também atuais:

A palavra "serviço de Deus" é compreendida e usada hoje num sentido muito impróprio. Quem a ouve não pensa nessas obras de Deus. Pensa no badalar dos sinos, na alvenaria e no madeiramento da igreja, no incensório, no brilho das velas, na conversa dentro da igreja, no ouro, na seda, nas pedras preciosas das vestes brancas e estolas, nos cálices e nas custódias, no órgão e nos quadros, na procissão e nas entradas solenes e, o que é mais importante, no palavrório e no desfiar do rosário. [...] Cantamos o Magnificat diariamente em voz alta e com grande pompa, mas silenciamos cada vez mais seu verdadeiro tom e sentido (p. 73).

\section{Considerações quase finais: bendizer Maria, modelo de fé e diaconia}

Lutero tem Maria em alta estima e consideração. Ela lhe deu consolo e alento em meio às turbulências que ele vivia. Ela lhe é modelo de fé e de resposta ativa e transformadora à ação de Deus na vida. Esta ação movimenta e transforma, e convida e clama por resposta. Para Lutero, Maria se dispôs a participar da ação de Deus, com toda sua vida, com todo seu corpo. Ela o fez, sem, contudo, chamar a atenção para si mesma, mas 'devolveu' toda honra e louvor a Deus, que atua em e por meio de nós.

Com sua análise do Magnificat de Maria, Lutero não poupou críticas a práticas marianas que praticamente se esqueciam de Deus. Destacou, por exemplo, que nele consta que Maria será bem-aventurada pelo fato de Deus ter baixado os olhos para ela na sua 'humildade'-insignificância, e não por causa do elogio de alguma virtude sua, de sua humildade ou virgindade. Em consequência, não é o fato de entoar cânticos a Maria, ou dirigir-lhe preces, que a dirá bem-aventurada: "Maria não gosta de ouvir os charlatães inúteis, que pregam e escrevem muito a respeito de seu mérito. [...] Pois quanto mais dignidade e mérito se atribui à mãe de Deus, tanto mais se prejudica a graça de Deus e se reduz a verdade do Magnificat" (p. 38). Quem assim o faz, insistentemente atribui a

d.1.Aufl. Berlin: Evangelische Verlagsanstalt, 1987, p. 358 (nota 338) entende por Menschwerdung "tornar-se pessoa/gente". 
Maria tanta honra e louvor, que "não estão longe de transformá-la em ídolo, como se ela desejasse ser honrada e se devesse esperar todo o bem dela. Maria rejeita isso e quer que Deus seja honrado nela e que, por intermédio dela todos sejam levados a confiar plenamente na graça de Deus" (p. 38-39). Louvada deve ser a misericordiosa graça de Deus que escolheu e atuou em Maria, que "atribui tudo inteiramente ao fato de Deus ter observado sua nulidade" (p. 38). Portanto, Maria expressa claramente este motivo que fará com que "todas as gerações" a dirão bem-aventurada, o que, para Lutero, é um convite para "aprender como honrar e servir a Deus devidamente" (p. 38). Contudo, não era isso que faziam "os louvadores que falam muito e os tagarelas inúteis [...] que buscam auxílio e consolo nela como num Deus" (p. 40).

A crítica de Lutero brota de exageros de práticas marianas em seu contexto ${ }^{21}$, que assim são avaliados no conjunto do desenvolvimento dos princípios teológico-hermenêuticos no movimento da Reforma. Ele insiste na centralidade do agir de Deus, também em e por meio de Maria. E, na certeza de que esse agir de Deus fortalece o coração em fé, esperança e amor, percebe, na análise do Magnificat e da ação libertadora de Deus, que "Maria não quer que você venha a ela, mas que você encontre Deus através dela" (p. 39)! Nem mesmo a maternidade de Maria, reconhecida, então, pelos dogmas cristãos como mãe de Deus, que também Lutero confessa, é apresentada, no Magnificat, como o motivo de sua bem-aventurança; também esta foi uma concretização da escolha e da ação de Deus. O fato de ela ser confessada "mãe de Deus" não faz dela um

idolo que possa conceder algo ou ajudar alguém, como acreditam alguns que clamam mais a ela do que a Deus e nela buscam refúgio. Maria nada dá, mas somente Deus [...] que é poderoso. [...] Maria não quer ser um idolo. Ela nada faz. Deus é que faz todas as coisas. Devemos suplicar a ela para que, por amor a ela, Deus faça o que pedimos (p. 44-45).

A humildade de Maria não reside, para Lutero, apenas no 'antes' de Deus ter baixado seus olhos para ela, mas também depois, nada tendo reclamado ou exigido para si mesma, nem mesmo a honra de ser chamada mãe de Deus. Também isto é, aliás, motivo de contemplação: "continuou sendo uma pobre cidadã no meio da massa de pessoas hu-

21 Nesse questionamento, Lutero afirma que bem-aventurar Maria "não se deve limitar a palavras, ajoelhações, inclinação da cabeça, tirar o chapéu, fazer imagens, construir igrejas - os maus também fazem isso" (p. 40). 
mildes. Oh, que coração simples e puro! Que pessoa admirável!" (p. 46). Essa humildade e a graça de Deus em reconhecê-la e nela atuar transcendem épocas, porque Maria remete toda honra e glória a Deus, a tal ponto que Lutero chegou a escrever que "devemos suplicar a ela", como "a todos os santos" (p. 45), o que, em todo o caso, é significativo, no sentido da intermediação. ${ }^{22}$ A questão é: o que, até que ponto e em que medida devemos dirigir súplicas a Maria? Lutero é claro na resposta: devemos suplicar-lhe para que Deus realize o que pedimos, o que precisamos, "por amor [de Deus] a ela", Maria! Maria, portanto, também é referencial daquilo que é necessário para nós: colocar-se a serviço. Com isso, Lutero reafirma o que desenvolveu em sua chave hermenêutica na interpretação do Magnificat: a realização é exclusivamente de Deus, mas Maria assume, também aqui, uma interação.

No Magnificat, a experiência, o cotidiano, o contexto presente e a análise do passado perpassam toda a reflexão, estudo, crítica e orientação. A ação de Deus se fez e continua, hoje; a participação das pessoas nessa ação se fez e pode continuar se fazendo, hoje; a centralidade da humildade e do despojamento de Maria está testemunhada no Magnificat e deve ser observada na espiritualidade mariana, também hoje. ${ }^{23}$ No centro estão a prática e a memória da misericórdia de Deus para 'comigo' e na história de seu povo, de geração em geração, cumprindo a promessa a Abraão (SOUZA, 2015). E, nessa misericórdia e na ação que dela resulta, Deus, por sua graça e bondade, mostra sua parcialidade em favor das pessoas pobres (GOLLWITZER, 1979, p. 23).

Para bem bendizer Maria, com base no Magnificat interpretado no Magnificat de Lutero, posso enfatizar e celebrar, numa perspectiva luterana ecumênica: sua alegria e seu louvor em resposta à ação misericordiosa de Deus; sua confissão da transformação inversiva da ação de Deus nas relações humanas; seu reconhecimento da centralidade dessa ação poderosa de Deus; sua disponibilidade e desapego na entrega total ao serviço que presta a Deus e à humanidade por meio de sua resposta positiva; sua atitude proativa e não auto-complacente; sua humildade ressignificada a partir da ação transformadora de Deus; sua inserção na

22 Acerca da teologia da intermediação e seus problemas, no tempo de Lutero, ver Deifelt (2003).

23 Esta permanência (des)continuada do significado da ação de Deus e da resposta à mesma é evidenciada, no grego, pelo uso dos aoristos, cuja ação pode ser entendida como profética, que remente ao passado, estando aberta ao presente-futuro. Ver também Boff (2006, p. 351-54). 
história do passado, presente e futuro; sua ação e testemunho proféticos. Desta forma, Maria também será bem-aventurada, hoje e futuramente. Desta forma, também hoje e futuramente, poderemos colocar-nos ao lado de Isabel que, no encontro com Maria, sentiu a presença do fruto daquele ventre e proferiu a primeira confissão de esperança que brota de relações transformadas pela ação misericordiosa de Deus! Por fim, com Lutero, devo expressar, hoje, a necessidade e o desejo de que quem governa, governe em favor de todo o povo, com justiça e misericórdia!

\section{Referências}

BOFF, Clodovis M. Mariologia Social: o significado da Virgem para a sociedade. São Paulo: Paulus, 2006.

DEIFELT, Wanda. Maria: uma santa protestante? Revista de Interpretação Bíblica Latino-Americana, Petrópolis, n. 46, v. 3, p. 119-134, 2003.

DREHER, Martin N. Apresentação. In: LUTERO. Magnificat: o Louvor de Maria. Adaptação do texto: Rui J. Bender. 2. impr. São Leopoldo: Sinodal; Aparecida: Santuário, 2015. p. 7-8.

DREHER, Martin N. História do Povo de Deus: uma leitura latino-americana. São Leopoldo: Sinodal, 2013.

GOLLWITZER, Helmut. Die Freude Gottes: Einführung in das Lukasevangelium. 9. Aulf. Gelnhausen/Berlin/Stein: Burckhardthaus-Verlag; Freiburg i.Br.: Christophorus-Verlag, 1979.

LUTERO, Martim. Magnificat: o Louvor de Maria. Adaptação do texto: Rui J. Bender. 2. impr. São Leopoldo: Sinodal; Aparecida: Santuário, 2015 [1521]. [Versão atualizada de Obras Selecionadas de Martinho Lutero. V. 6. São Leopoldo: Sinodal; Porto Alegre: Concórdia, 1996. p. 20-78]

LUTERO, Dr. Martinho. Catecismo Maior. In: Livro de Concórdia: As Confissões da Igreja Evangélica Luterana. Tradução e notas de Arnaldo Schüler. São Leopoldo: Sinodal; Porto Alegre: Concórdia, 1980. p. 385-496.

MURAD, Afonso. Maria, toda de Deus e tão humana. 3. ed. São Paulo: Paulinas; Valência: Siquem, 2009. 
PELIKAN, Jaroslav. Maria através dos séculos: seu papel na história da cultura. Tradução de Vera C.Guarnieri. São Paulo: Companhia das Letras, 2000.

REVISTA de Interpretação Bíblica Latino Americana, Petrópolis, v. 46 (2003) e especificamente, no v. 44 (2003).

RICHTER REIMER, Ivoni. Maria, Jesus e Paulo com as mulheres: textos, interpretações e história. São Paulo: Paulus; São Leopoldo: CEBI, 2013.

RICHTER REIMER, Ivoni. Compaixão, cruz e esperança: Teologia de Marcos. São Paulo: Paulinas, 2012.

RICHTER REIMER, Ivoni. Maria sempre bendita: textos e imaginários de uma história que se faz, desfaz e refaz. In: . (Org.). Imaginários da divindade: textos e interpretações. São Leopoldo: Oikos; Goiânia: Ed. da UCG, 2008. p. 101-124.

. E a salvação se fez corpo: Lucas 1-2 numa perspectiva feminista. Revista de Interpretação Bíblica Latino-Americana, Petrópolis, v. 44, p. 37-59, 2003.

SEILS, Martin. Das Magnificat verdeutscht und ausgelegt, 1521. In: DELIUS, Hans-Ulrich (Hg.). Martin Luther: Studienausgabe. Bd. 1. 3.Nachdr. d.1.Aufl. Berlin: Evangelische Verlagsanstalt, 1987. p. 312-364.

SCHNEEMELCHER, Wilhelm (Hg.). Neutestamentliche Apokryphen in deutscher Übersetzung. 5. ed. Tübingen: Mohr, 1987, v. I.

SOUZA, Carolina Bezerra de. Magnificat: o canto do corpo grávido e pobre. In: RICHTER REIMER, Ivoni (Org.). Por amor à vida! Crenças, resistências e conquistas na Bíblia e na atualidade. Goiânia: Ed. da PUC Goiás, 2015. p. 93-110. 